\title{
ISOLASI, IDENTIFIKASI DAN KARAKTERISASI PENYEBAB PENYAKIT BERCAK DAUN PADA SEMAI PINUS DI PERUM PERHUTANI BKPH PURWOREJO, KPH KEDU SELATAN
}

\author{
Isolation, identification and characterization of leaf spot disease causal agent on pine \\ seedling at Perum Perhutani, BKPH Purworejo, KPH Kedu Selatan
}

\author{
Nur Hidayati ${ }^{1}$, Siti Husna Nurrohmah ${ }^{1}$, dan Fithry Ardhany ${ }^{1}$ \\ ${ }^{1}$ Kontributor Utama, ${ }^{1}$ Balai Besar Penelitian dan Pengembangan Bioteknologi dan Pemuliaan Tanaman Hutan, \\ Jl. Palagan Tentara Pelajar KM 15, Purwobinangun, Pakem, Sleman, Yogyakarta, Indonesia \\ email penulis korespondensi: inunghidayati@yahoo.com
}

Tanggal diterima: 09 April 2020, Tanggal direvisi: 09 April 2020, Disetujui terbit: 19 Juni 2020

\begin{abstract}
Pinus merkusii, a multiuse tree, is cultivated at Indonesian Plantation. Pinus plantation have been threatened by rust/spot leaf disease. The pathogen has infected pinus seedlings at Perum Perhutani, BKPH Purworejo, KPH Kedu Selatan and cause high mortality. The aims of this research to identify pathogen causing rust/spot leaf thus information how to control can be observed. Pathogens were isolated from infected leaves, and grown on the potato dextrose agar (PDA) and observed macroscopis and microscopis and identified. The pathogens also were inoculated to healthy seedlings (Postulat Koch Test). The result shows that pathogen causing rust/spot leaf on seedlings pine is Pestalotia sp with characteristic white colony, hypha has acervuli with conidia that have 25 septums and 3 or 5 whip like structures at the edge. Potulat Koch test indicated that inoculated healthy seedling shows similar symptom with infected seedlings. Rust/spot leaf has similar symptom and sign. Spot or rust appear on leaves started from edge and spread to base. At first, spots were formed in small size and separate each other but they developed and became larger and fused.
\end{abstract}

Keywords: pathogen, Pestalotia sp, inoculation, acervuli, hypha

\begin{abstract}
ABSTRAK
Pinus merkusii merupakan tanaman serbaguna yang banyak dibudidayakan di Indonesia. Namun budidaya tanaman pinus kini tengah menghadapi serangan penyakit bercak daun. Penyakit ini juga menyerang semai pinus di Perum Perhutani, BKPH Purworejo, KPH Kedu Selatan dan menyebabkan tingkat kematian yang tinggi. Tujuan dari penelitian ini adalah untuk mengidentifikasi patogen penyebab karat daun pada semai pinus sehingga dapat diketahui cara mengendalikannya. Patogen diisolasi dari daun yang terinfeksi, ditumbuhkan pada media potato dextrose agar (PDA). Selanjutnya diamati baik secara makroskopis maupun mikroskopis dan diidentifikasi. Kemudian diinokulasi pada tanaman sehat (uji Postulat Koch). Hasil identifikasi menunjukkan bahwa patogen penyebab penyakit bercak daun pada semai pinus adalah Pestalotia sp. yang dicirikan dengan koloni berwarna putih, hifa memiliki aservuli dengan konidia bersekat 2-5 dan pada ujungnya terdapat seperti bulu cambuk berjumlah 3 atau 5. Hasil Uji postulat Koch pada semai pinus sehat yang diinokulasi menunjukkan gejala yang sama dengan semai yang telah terinfeksi. Semai yang terinfeksi patogen bercak daun mengalami gejala pada daun-daunnya muncul bercak-bercak kuning diawali dari pucuk daun jarum menyebar kearah pangkal. Bercak terpisah tidak beraturan tapi kemudian membesar dan menyatu.
\end{abstract}

Kata kunci: patogen, Pestalotia sp, inokulasi, aservuli, hifa

\section{PENDAHULUAN}

Pinus termasuk dalam jenis pohon serba guna terutama dalam produksi kayu dan getah (Supriyanto \& Iskandar, 2018). Getah sadapan merupakan hasil utama dari pohon pinus serta kayunya juga dapat diolah untuk pembuatan korek api, kertas serat panjang, pulp dan sebagai bahan baku kontruksi. Selain itu pinus juga berperan dalam menjaga serta mengendalikan kondisi hidrologis kawasan bahkan juga mendukung industri ekowisata (Sutarman, 2018). Oleh karena itu, hutan pinus perlu dikembangkan dan dikelola dengan baik. Salah satu hal yang diperlukan untuk mendukung pengembangan hutan pinus adalah penggunaan bibit-bibit pinus yang sehat dan berkualitas.

Pengadaan bibit tanaman kehutanan yang berkualitas, baik dalam jumlah yang cukup dan 
waktu yang tepat merupakan salah satu faktor penentu keberlangsungan pengelolaan hutan. Dalam budidaya hutan, serangan hama dan penyakit menjadi salah satu faktor pembatas yang menentukan keberhasilan penanaman baik di persemaian maupun di lapangan (Suharti \& Kurniaty, 2013). Kesehatan tanaman di persemaian merupakan langkah awal yang menentukan keberhasilan penanaman. Adanya penyakit di persemaian, yang disebabkan oleh patogen dapat menyebabkan kematian tanaman pada tingkat semai sehingga menimbulkan kekurangan jumlah bibit. Persemaian menjadi faktor yang menentukan dalam penyediaan bibit. Umur semai yang seragam dan jenis yang sama akan memudahkan bibit tanaman diserang oleh patogen (Saragi, Firdara, \& Putir, 2019). Menurut Sutarman (2018), adanya gangguan patogen penyebab penyakit merupakan salah satu faktor yang mengancam keberlangsungan hutan pinus.

Tanaman di persemaian biasanya banyak diserang oleh penyakit karat, bercak daun, mosaik, embun tepung dan sebagainya (Irawan, Anggraeni, \& Christita, 2015). Salah satu penyakit yang dijumpai pada tanaman pinus adalah penyakit bercak daun/hawar daun terutama di persemaian. Penyakit bercak daun merupakan penyakit pada daun di persemaian yang banyak disebabkan oleh berbagai patogen antara lain Pestalotia sp, Cercospora sp (Bambang, Diba, \& Anwari, 2019; Hariyanto, Jumani, \& Heni, 2014; Irawan et al., 2015; Suharti \& Kurniaty, 2013), Colleotrichum sp (Irawan et al., 2015), Lasidioplodia sp, Helminthosporium $\mathrm{sp}$, dan Gloesporium $\mathrm{sp}$ (Anggraeni, 2009). Penyakit bercak daun pada umumnya menyerang daun-daun bagian bawah kemudian menyebar pada daun bagian atas. Gejala bercak daun muncul pada daun, tangkai daun bahkan batang. Selanjutnya bercak berubah menjadi pustul seperti karat (Rabuansyah, Iskandar, \& Suryatini, 2014).

Penyakit bercak daun bisa jadi belum menimbulkan kerugian secara ekonomis namun secara fisiologis menyebabkan kerugian besar pada tanaman karena merusak daun sehingga dapat menghambat proses fotosintesis dan bisa menyebabkan kematian pada bibit tanaman, dalam skala luas dapat menyebabkan gagal tanam (Anggraeni, 2009; Anggraeni \& Mindawati, 2011). Tanaman yang terinfeksi bercak daun biasanya akan menjadi lemah sehingga akan memicu tanaman untuk memproduksi buah yang mengakibatkan menipisnya cadangan makanan yang terdapat pada akar yang dikuti kematian ranting bahkan tanaman itu sendiri juga mati. Hal tersebut dapat menyebabkan terjadinya penurunan hasil panen. Kerugian akibat serangan penyakit bercak daun sulit diprediksi karena dampaknya bisa dirasakan hingga beberapa tahun setelah munculnya serangan (Semangun, 2006). Dampak serangan bercak daun perlu segera diminimalkan dengan melakukan pencegahan dan pengendalian sebelum terjadinya wabah, mengingat banyak faktor yang dapat menyebabkan peningkatan intensitas serangan bercak daun bahkan dapat terjadi wabah. Menurut Sutarman dan Prihatiningrum (2015) perubahan iklim dapat memicu terjadinya wabah. Perubahan iklim dapat menimbulkan gangguan oleh faktor biotik antara lain munculnya ataupun meningkatnya serangan hama dan patogen. Jamur patogen sangat dipengaruhi oleh kelembaban dan suhu sehingga perubahan lingkungan akan memicu resiko serangan penyakit, oleh karena itu perlu menjaga dan memantau perkembangan penyakit pada tanaman (Garret et al., 2016; Raitelaitytè, Rutkauskas, \& Žukauskienè, 2016).

Penyakit karat/bercak/hawar daun telah menyerang pinus di hampir seluruh persemaian utama hutan pinus di kawasan Jawa Timur (Sutarman \& Prihatiningrum, 2015). Semai Pinus di persemaian BKPH Purworejo, KPH Kedu Selatan, Perum Perhutani Jawa Tengah juga menunjukkan gejala serangan bercak daun bahkan menyebabkan kematian. Agar dapat menetapkan cara mengendalikan serangan bercak daun maka hal pertama yang harus dilakukan adalah kegiatan identifikasi 
mikroorganisme atau patogen yang menyebabkan terjadinya penyakit. Patogen dapat diidentifikasi dengan cara mengisolasi mikroorganisme patogen dari tanaman yang terinfeksi. Dalam kegiatan identifikasi perlu dilakukan kegiatan isolasi terlebih dahulu untuk memperoleh mikroorganisme yang menjadi penyebab penyakit sehingga dapat diperoleh informasi tentang patogen tersebut. Isolasi adalah proses yang bertujuan untuk memperoleh biakan murni suatu mikroorganisme tertentu dengan cara memisahkan mikroorganisme dari populasi beragam dan menumbuhkannya pada media buatan. Inokulasi merupakan proses penularan patogen dari sumber inokulum terhadap tanaman yang sehat. Setelah dilakukan inokulasi tanaman dapat terinfeksi patogen sehingga timbul gejala penyakit. Langkah selanjutnya adalah identifikasi yaitu kegiatan untuk mencocokkan antara gejala tanaman yang terinfeksi patogen serta gambaran patogen yang diperoleh dari hasil isolasi dengan informasi terdahulu baik dari buku, jurnal dan pustaka lainnya (Perhutani, 1999). Penelitian ini bertujuan untuk mengetahui penyebab penyakit bercak daun pada semai Pinus di BKPH Purworejo, KPH Kedu Selatan, Perum Perhutani Jawa Tengah.

\section{BAHAN DAN METODE}

\section{A. Waktu dan lokasi penelitian}

Penelitian dilakukan sejak tanggal 21 Januari 2019 hingga 15 Februari 2019, di Laboratorium Hama dan Penyakit, Balai Besar Penelitian dan Pengembangan Bioteknologi dan Pemuliaan Tanaman Hutan (BBPPBPTH), Yogyakarta.

\section{B. Bahan dan alat penelitian}

Bahan yang digunakan dalam penelitian ini, yaitu semai pinus (Pinus merkusii), pasir, akuades steril, suspensi jamur Pestalotia sp., lactopenol blue, Potato Dextrose Agar (PDA) bubuk 39 gram/liter, air, sunlight, bayclin, alkohol $70 \%$ dan $96 \%$.
1. Alat

Alat yang digunakan meliputi baki, polibag, gelas objek, cover glass, beaker glass, gunting, botol kultur, sprayer, plastik, pita, spidol, kain, kamera, timbangan digital, wadah, sendok, botol Schott Duran, autoklaf, alumunium foil, Laminar Air Flow (LAF), bunsen, korek, cawan petri, wrapping plastic, label, pinset, tissu, scalpel, batang Drygalski (alat perata), kain saring, mikrotube, mikroskop, masker, ember, haemocytometer, alat tulis, mikropipet dan tip.

\section{Metode penelitian}

\section{Sterilisasi alat}

Sterilisasi dilakukan untuk mensterilkan alat dan bahan yang akan digunakan dengan menggunakan autoklaf®. Sterilisasi alat dilakukan selama 30 menit dan bahan selama 20 menit pada suhu $121^{\circ} \mathrm{C}$ tekanan $1 \mathrm{~atm}$.

\section{Pembuatan media potato dextrose agar (PDA)}

Potato Dexrose Agar (PDA)® ditimbang 23,4g dimasukkan ke dalam botol Schott Duran kemudian ditambah $600 \mathrm{ml}$ aquades, dihomogenkan dengan digojog secara manual, kemudian disterilisasi di autoklaf pada suhu $121^{\circ} \mathrm{C}$ tekanan 1 atm selama 20 menit. Penuangan media pada cawan petri dilakukan dalam keadaan steril di LAF (Laminar Air Flow)®.

\section{Persiapan isolasi jamur patogen dari beberapa semai pinus}

Langkah pertama adalah menyiapkan 4 cawan petri steril untuk meletakkan daun semai pinus yang akan diisolasi. Patogen jamur diisolasi dengan menggunakan metode tanam langsung yaitu mikroorganisme ditumbuhkan secara langsung pada media tumbuh. Dari semai pinus yang menunjukkan gejala penyakit bercak daun, diambil bagian yang sakit sebanyak 4 bagian, ditanam pada media PDA kemudian diberi label dan di-wrapping (ditutup menggunakan plastik bagian pinggirnya). Tiap 
semai diambil sebanyak 3 kali ulangan. Pengamatan dilakukan setiap hari. Jika sudah menunjukkan adanya miselium jamur dapat disubkultur untuk mendapatkan biakan murni.

\section{Subkultur hasil isolasi jamur patogen}

Hasil isolasi patogen jamur pada media PDA yang telah tumbuh miseliumnya disubkultur dengan cara mengambil sekotak kecil bagian miselium paling luar kemudian ditanam pada media PDA baru dengan 5 kali ulangan sehingga didapatkan biakan murni. Subkultur diberi label serta tanggal pembuatan dan difoto tiap dua hari sekali.

\section{Panen spora hasil subkultur jamur patogen}

Hasil subkultur dipanen sporanya dengan cara menyiapkan air steril sebanyak $30 \mathrm{~mL}$ yang dimasukkan dalam botol steril dan semua bagian isolat subkultur kemudian dikocok secara manual beberapa kali selama 30 menit untuk melepaskan sporanya. Selanjutnya dituang kedalam botol steril lainnya sambil disaring dengan kain untuk mendapatkan suspensi spora.

\subsection{Penghitungan spora}

Hasil suspensi jamur patogen dan lactopenol cotton blue diambil dengan mikropipet sebanyak $50 \mu \mathrm{L}$ lalu dimasukkan dalam mikrotube $1,5 \mu \mathrm{L}$ kemudian dicampur dengan cara disentil mikrotubenya. Penghitungan spora dilakukan dengan cara mengambil suspensi dalam mikrotube sebanyak $20 \mu \mathrm{L}$ dengan mikropipet yang kemudian dimasukkan disela-sela haemocytometer ${ }^{\circledR}$ lalu diamati di bawah mikroskop dan dihitung dengan menggunakan rumus:

Jumlah spora $=$

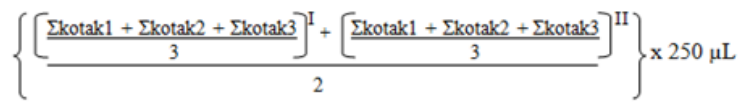

Keterangan: I= Kotak bagian atas, II= Kotak bagian bawah

\subsection{Plating}

Hasil suspensi jamur patogen diambil sebanyak $20 \mu \mathrm{L}$ dengan mikropipet lalu diteteskan pada media PDA dan MEA di cawan petri kemudian diratakan dengan batang dryglaski. Jika dianggap sudah rata cawan petri diwrap dan diberi label nama serta tanggal pembuatan. Plating diamati dan difoto setiap hari, serta diberi tanda jika terdapat spora.

\section{Inokulasi hasil suspensi jamur patogen}

Hasil suspensi jamur patogen yang sudah didinginkan dalam lemari es diambil semua kemudian dimasukkan dalam sprayer dan disemprotkan pada 4 semai pinus. Hasil analisis jumlah konidia jamur Pestalotia sp. menggunakan haemocytometer didapatkan sebanyak 542,5 konidia/ $\mu \mathrm{L}$ atau 542500 konidia/mL. Konsentrasi spora yang digunakan untuk inokulasi sebanyak $5 \times 10^{6}$. Setelah disemprot semai pinus ditutup dengan plastik supaya spora menempel pada semai kemudian diberi label dan tanggal inokulasi. Inokulasi diamati dengan melihat perubahan morfologi tanamannya.

\section{Pengamatan morfologi isolat}

\subsection{Makroskopis}

Pengamatan dilakukan setiap hari, isolat yang diinokulasikan pada semai pinus yang sehat diamati perubahan morfologinya, seperti perubahan warna daun dan gugur daun. Perubahan morfologi tersebut merupakan gejala penyakit yang ditimbulkan oleh jamur patogen. Penyiraman terhadap semai pinus dilakukan setiap hari.

\subsection{Mikroskopis}

Miselium jamur bagian pinggir diambil menggunakan scalpel, kemudian diletakkan pada gelas objek. Miselium ditetesi lactopenol blue sebanyak satu kali dengan volume $20 \mu \mathrm{L}$. Ditutup dengan gelas penutup kemudian ditekan sudut dari gelas penutup dengan hati-hati. Miselium diamati di bawah mikroskop dengan perbesaran 40x kemudian dicari morfologi mikroskopiknya yang lengkap lalu difoto untuk data laporan. 


\section{Identifikasi jamur penyebab penyakit bercak daun}

$\begin{array}{crr}\text { Hasil } & \text { pengamatan } & \text { miselium } \\ \text { menggunakan } & \text { mikroskop, } & \text { kemudian }\end{array}$ diidentifikasi dengan cara membandingkan hasil pengamatan morfologi isolat mikroskopik dengan buku referensi (Barnett \& Hunter, 1972).

\section{Analisis data}

Pengamatan dilakukan secara mikroskopis dan makroskopis kemudian data dianalisis secara deskriptif kualitatif.

\section{HASIL DAN PEMBAHASAN}

Hasil pengamatan di lapangan diperoleh bahwa telah terjadi kematian semai pinus di KPH Kedu Selatan. Dari pengamatan gejala dan tanda dapat diketahui semai yang mati menunjukkan adanya gejala daun-daun yang mengering sebagian, selanjutnya bila serangan berlanjut daun pada semai akan mengering secara menyeluruh. Kematian semai terjadi setelah 3 bulan penyapihan. Tabel 1 . Menunjukkan kronologi kematian semai di persemaian Petak 51m RPH Bruno, BKPH Purworejo, KPH Kedu Selatan.

\section{A. Gejala dan tanda kematian semai pinus}

Hasil pengamatan menunjukkan bahwa kematian semai pinus sampai dengan bulan Juli 2018 sebesar $66,94 \%$ dari 41.319 semai.

Tabel 1. Kegiatan persemaian pinus di RPH Bruno, BKPH Purworejo, KPH Kedu Selatan

\begin{tabular}{lllllll}
\hline No. & Uraian kegiatan & Satuan & Rencana & Realisasi & $\%$ & Waktu \\
\hline 1. & Penaburan benih & $\mathrm{Kg}$ & 3,20 & 3,20 & 100 & 26 Oktober2017 \\
2. & Benih berkecambah & $\mathrm{Plc}$ & 41.319 & 41.319 & 100 & \\
3. & Penyapihan & $\mathrm{Plc}$ & 41.319 & 41.319 & 100 & \\
4. & Kematian & $\mathrm{Plc}$ & & 2.195 & 5,31 & 26 Februari 2018 \\
& & & 4.505 & 10,9 & 16 April 2018 \\
& & & 11.438 & 27,68 & 22 Mei 2018 \\
& & & 9,521 & 23,04 & 27 Juli 2018 \\
\hline & Jumlah kematian & Plc & & 27,659 & 66,94 & \\
& Sisa bibit & Plc & & 13.660 & 33,06 & \\
\hline
\end{tabular}

Sumber : BKPH Purworejo, KPH Kedu Selatan

Kematian semai diawali dengan timbulnya bercak-bercak kuning pada daun jarum semai, yang kemudian meluas sehingga daun-daun jarum tampak menguning (klorosis). Tanaman yang terserang parah menunjukkan gejala nekrosis. Bagian yang mengering lebih dahulu biasanya dari pucuk daun jarum menjalar kearah pangkal. Daun-daun menjadi kering dimulai dari daun-daun bagian bawah semai berlanjut sampai daun-daun dipucuk semai. Pada akhirnya seluruh daun menjadi kering kadang tersisa bagian hijau dipucuknya saja sehingga menyebabkan kematian semai pinus. Hasil pengamatan menunjukan bahwa dalam satu persemaian dapat diserang satu atau beberapa patogen. Gejala tersebut ditandai dengan adanya bercak berwarna coklat muda sampai coklat tua diseluruh atau sebagian daun semai pinus. Bentuk bercak tidak beraturan dimana satu sama lain saling terpisah namun lambat laun bercak tersebut akan membesar dan menyatu (Gambar 1).

Pada beberapa tanaman pertanian dan perkebunan, penyakit bercak daun dapat menurunkan nilai ekonomi tanaman. Pada anggrek, penyakit bercak daun menyebabkan adanya lesi sehingga mengurangi keindahan dan nilainya turun (Yimcharoen, Tongon, Song, \& Soytong, 2019). Penyakit bercak daun yang disebabkan oleh Pestalotia sp juga dapat menurunkan produksi tanaman agrikultur segar sebagai penyakit yang menyerang tanaman baik pra maupun pasca panen (Sharma \& Kulshrestha, 2015).

Namun pada sebagian besar tanaman, penyakit daun tidak menimbulkan kerugian 
ekonomi yang signifikan sehingga sering kali tidak diperhitungkan dampaknya. Dampak kerugian yang terbesar akibat dari penyakit daun adalah pada aspek fisiologis. Fungsi daun yang merupakan organ fotosintesis akan terganggu (Anggraeni, Intari, \& Darwiati, 2006). Fotosintesis berperan untuk melanjutkan segala fungsi sel dari tumbuhan. Patogen

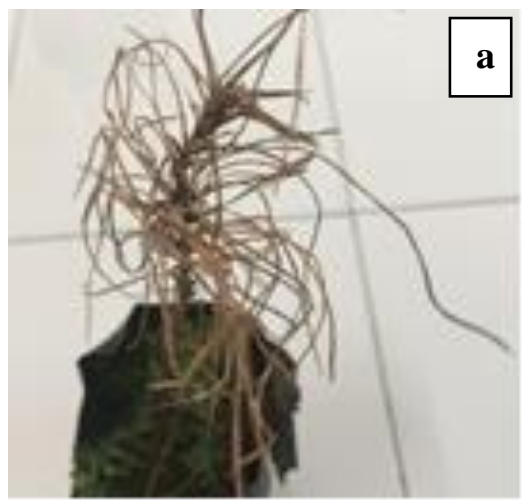

Gambar 1. (a) Gejala bercak daun pada semai pinus,

Berdasarkan pengamatan gejala penyakit pada semai pinus di Petak $51 \mathrm{~m}$ RPH Bruno BKPH Purworejo KPH Kedu Selatan, penyakit utama yang menyerang tanaman pinus adalah penyakit bercak daun yang disebabkan oleh patogen Pestalotia sp. Gejala yang timbul serupa dengan gejala penyakit bercak daun pada pinus ataupun tanaman lain. Pada umumnya penyakit bercak daun yang disebabkan oleh Pestalotia sp, diawali dengan munculnya titik/noda/bercak kecil dengan bentuk yang tidak beraturan (Bambang et al., 2019; Hariyanto et al., 2014; Moustafa, Hala, ElDakar, \& Alkolaly, 2015; Saragi et al., 2019; Suharti \& Kurniaty, 2013). Warna bercak bervariasi tergantung tanaman dan patogen. Namun pada umumnya bercak berwarna kuning atau coklat dengan tepi lebih tebal dan warna lebih gelap (Bambang et al., 2019; Hariyanto et al., 2014; Irawan et al., 2015) pada beberapa tanaman yang terinfeksi Pestalotia sp, warna bercak ada yang berubah menjadi abu-abu atau putih keabu-abuan seperti pada tanaman jabon merah (Hidayah \& Anggraeni, 2015), cinnamon (Wadud, Fahim, Sarker, \& Uddin, 2017), menyebabkan pengurangan luas permukaan efektif untuk berfotosintesis (Sinaga, 2000). Apabila luas daun untuk berfotosintesis berkurang maka pertumbuhan tanaman akan terganggu. Jika dibiarkan akan mengakibatkan seluruh proses fotosintesis pada daun tidak terjadi dan akhirnya tanaman mati (Anggraeni \& Mindawati, 2011).

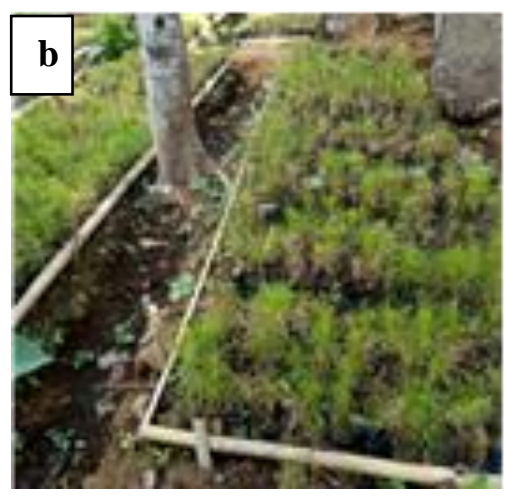

Carissa carrandas (Jarial \& Jarial, 2016) dan kelapa (Manikandan et al., 2019). Selanjutnya bercak-bercak tersebut membesar dan bergabung dengan bercak lainnya sehingga bercak menjadi luas dan menutupi sebagian atau seluruh permukaan daun. Pada tahap selanjutnya daun mengalami klorosis, kering dan gugur sebelum waktunya dan akhirnya tanaman mati (Bambang et al., 2019; Jarial \& Jarial, 2016; Moustafa et al., 2015; Saragi et al., 2019; Wadud et al., 2017). Di Jawa Timur dilaporkan bahwa Pestalotia theae secara konsisten merupakan penyebab utama penyakit bercak daun pada tanaman pinus. Pestalotia dapat menginfeksi semai pinus usia 1 bulan bahkan sampai semai yang siap tanam. Gejala yang ditimbulkan adalah daun menjadi kering diawali dari bagian ujung kemudian berkembang pada seluruh daun dan menyebabkan kematian daun yang mana daun yang jatuh atau gugur sekaligus membawa konidiospora yang dapat menjadi sumber patogen (Sutarman, 2018).

Pestalotia sp memiliki sebaran yang luas dan banyak dilaporkan sebagai jamur atau 
cendawan penyebab penyakit bercak daun pada berbagai tanaman baik tanaman pertanian, kehutanan, ornamental ataupun bunga dan buahbuahan antara lain jabon merah (Anthocephalus macrophyllus) (Hidayah \& Anggraeni, 2015), Shorea belangeran (Saragi et al., 2019), Eucalyptus pellita (Arsensi, Lahjie, Simarangkir, \& Mardji, 2016), Vitellaria paradoxa (Akrofi \& Amoah, 2009), Cinnamomum tamala (Wadud et al., 2017). $P$. diospyri menginfeksi tanaman Dyospiros melanoxylon (Mehta, Jain, \& Rajkumar, 2020). $P$. longisetula menyerang stroberi (Mouden, Benkirane, Touhami, \& Douira, 2014), P. heterocornus pada Anacordium occidentale (Wonni et al., 2017), P.carissae pada Carissa carandas (Jarial \& Jarial, 2016), P. psidii pada jambu biji (Moustafa et al., 2015), P. palmarum dilaporkan telah menginfeksi tanaman kelapa (Manikandan et al., 2019; Rahman, Adhikary, Sultana, \& Jahan, 2013) dan Allanblackia floribunda (Olasupo, Adegeye, \& Olajuyigbe, 2020). Hasil penelitian penyakit bercak daun pada mangga ditemukan beberapa jenis Pestalotia antara lain P. mangiferae (Fatima \&
Khot, 2017), P. versicolor (Jarial, Jarial, Thakur, Banyal, \& Mandradia, 2017) dan P. anacardii (Patil, Mehta, Deshmukh, \& Bavalgave, 2019). Pestalotia sp juga menyerang anggrek (Yimcharoen et al., 2019), Chamaecyparis lawsoniana (Motlagh \& Rad, 2017), dan tanaman azalea (Rhododendron) (Moshayedi, Rahanandeh, \& Hamzeh, 2017).

\section{B. Isolasi dan identifikasi jamur}

Isolat yang teridentifikasi memiliki ciriciri morfologi yang dapat diamati secara makroskopis dan mikroskopis. Hasil isolat yang diidentifikasi memiliki miselium berwarna putih dengan tepian berwarna putih. Hal ini sesuai dengan morfologi beberapa isolat Pestalotia, Menurut Jarial dan Jarial (2016), P. carissae sp. sebagai penyebab penyakit bercak daun pada tanaman Carissa carandas memiliki ciri-ciri morfologis miselium berwarna putih, berbentuk seperti kapas dan pada waktu isolat sudah tua berwarna abu-abu terang. Hasil penelitian Madhi (2016) juga menyatakan bahwa miselium Pestalotia mempunyai karakter seperti kapas berwarna putih.
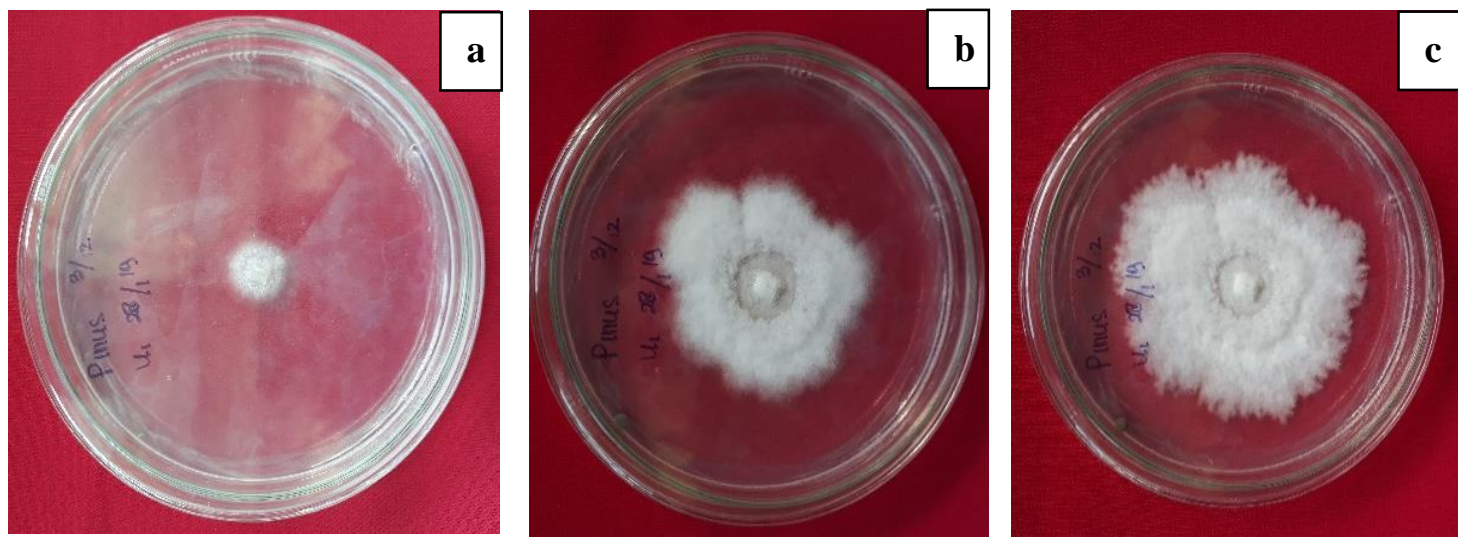

Gambar 2. (a) Isolat Pestalotia sp. Hari ke-2, (b) Isolat Pestalotia sp. Hari ke-9, (c) Isolat Pestalotia sp. Hari ke-15

Pertumbuhan isolat jamur Pestalotia sp. relatif lambat, meskipun telah mencapai hari ke15 , pertumbuhannya belum memenuhi cawan petri (Gambar 2c.). Pada miselium jamur Pestalotia sp yang sudah tua nampak terbentuk seperti badan buah kecil berwarna hitam yang disebut dengan aservuli (Gambar 3a) (Madhi, 2016; Moustafa et al., 2015). Aservuli biasanya juga dijumpai pada daun tanaman yang terinfeksi, aservuli berwarna gelap diproduksi pada lesi yang lebih tua (Wadud et al., 2017) Aservuli berwarna hitam berbentuk seperti telur nampak pada permukaan daun (Manikandan et al., 2019). Aservuli pada miselium diambil sedikit untuk diamati dibawah mikroskop. Hasil pengamatan menunjukkan aservuli memiliki 
konidia berbentuk lonjong atau oval dengan bagian ujung agak meruncing. Konidia memiliki dinding tebal berwarna hitam dan mempunyai sekat 2-5. Pada konidia terdapat struktur seperti rambut atau bulu cambuk dengan jumlah 3, 4 atau 5 yang terletak pada salah satu ujungnya (Gambar 3b). Berdasarkan ciri-ciri tersebut jamur patogen yang menyebabkan penyakit bercak daun pada semai pinus adalah Pestalotia sp (Barnett \& Hunter, 1972).

Klasifikasi menurut (Streets, 1972), yaitu:

Class

: Deuteromycetes

Ordo

: Melanconiales

Familia

: Melanconiaceae

Genus

: Pestalotia

Spesies

: Pestalotia sp.

Karakteristik lain yang dimiliki jamur patogen ini, antara lain arah pertumbuhan yang ke samping, bentuk miselium kasar (Gambar 2), serta konidiofor berwarna hialin pendek dan

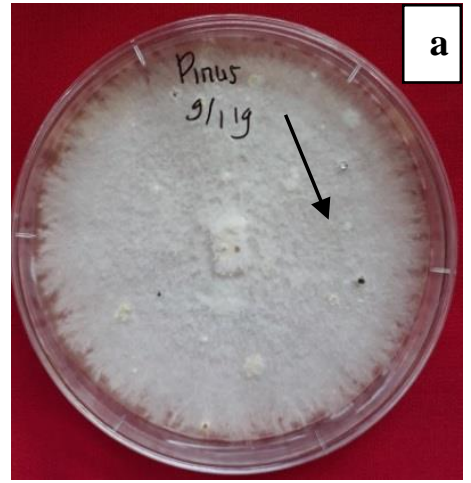

Gambar 3. (a) Isolat Pestalotia sp. yang akan diamati, (b) Konidia Pestalotia sp. di bawah mikroskop perbesaran 40x

Mekanisme infeksi jamur patogen dapat terjadi melalui penetrasi langsung dengan menembus permukaan tanaman inang, melalui luka ataupun melalui lubang alami yaitu stomata. Hifa dapat menghasilkan enzim kutinase yang berfungsi sebagai biokatalisator untuk menghancurkan kutikula sehingga miselium dapat tumbuh pada kutikula dan dinding sel epidermis. Jamur patogen akan menembus sel agar bisa memperoleh nutrisi dari sel tersebut sehingga dapat menjalankan proses metabolisme dan reproduksi. Jamur patogen akan tumbuh dan berkembang pada tanaman sehingga menyebabkan kerusakan pada tanaman (Gao, Dai, \& Liu, 2010). Proses infeksi patogen nyaris tidak terlihat (Gambar 3b). Percabangan hifa bercabang dan tidak lurus, tidak bersekat, serta berwarna gelap. Menurut Barnett dan Hunter (1972), Konidiofor terdiri dari beberapa sel yang berwarna gelap dan sel ujung yang meruncing berwarna jemih (hialin), sedangkan bagian ujung sel terdapat dua atau lebih tonjolan. Konidiosfor pendek dan simple, konidia berbentuk gelendong atau elips (Madhi, 2016), konidium bersel 5 berukuran 22-27 x 7$10 \mu \mathrm{m}$. Tiga sel yang di tengah berwama gelap, satu sel diantaranya lebih pucat dan lebih kecil dari pada dua lainnya. Sel-sel basal hialin dan kecil dengan tangkai 4-7 $\mu \mathrm{m}$. Sel ujung hialin, kecil, dengan 3-4 seta yang lentur, dan memencar dengan ukuran 17-27 x $1 \mu \mathrm{m}$ (Semangun, 2000). Pada bagian ujung konidiospora terdapat struktur mirip antena berukuran 25-40 $\mu \mathrm{m}$, jumlahnya 2-3 (Sutarman, 2018).

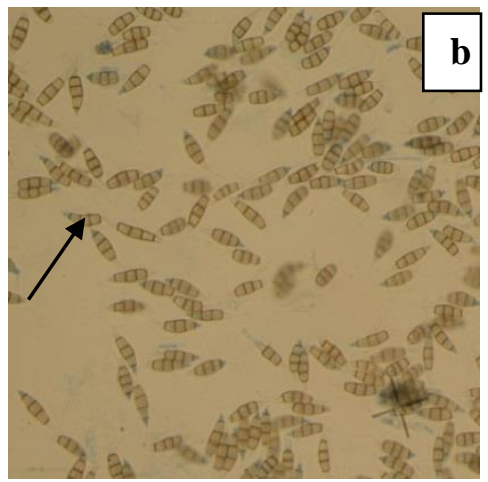

pada umumnya, diawali propagul yang berada di lingkungan yang sesuai akan berkecambah akan membentuk apresorium untuk melakukan penetrasi. Setelah penetrasi hifa akan tumbuh membentuk haustorium yang berfungsi untuk menyerap makanan dari tanaman inang. Selanjutnya patogen akan berkembang (Hidayah \& Anggraeni, 2015)

\section{Uji patogenitas (Postulat Koch)}

Hasil dari uji Postulat Koch dengan menginokulasi jamur patogen penyebab bercak daun pada semai pinus yang sehat menimbulkan gejala yang sama dengan semai yang terserang penyakit bercak daun (hari ke-13 setelah 
Isolasi, Identifikasi dan Karakteristik Penyebab Penyakit Bercak Daun Pada Semai Pinus di Perum Perhutani BKPH Purworejo, KPH Kedu Selatan Nur Hidayati, Siti Husna Nurrohmah dan Fithry Ardhany

inokulasi) (Gambar 4c). Hal tersebut menunjukkan bahwa jamur patogen yang menyerang persemaian pinus sesuai dengan yang telah diidentifikasi. Tanaman yang tidak diinokulasi (kontrol) tampak sehat tanpa ada gejala sedangkan tanaman yang diinokulasi memperlihatkan gejala yaitu perubahan warna daun dan juga munculnya miselium pada

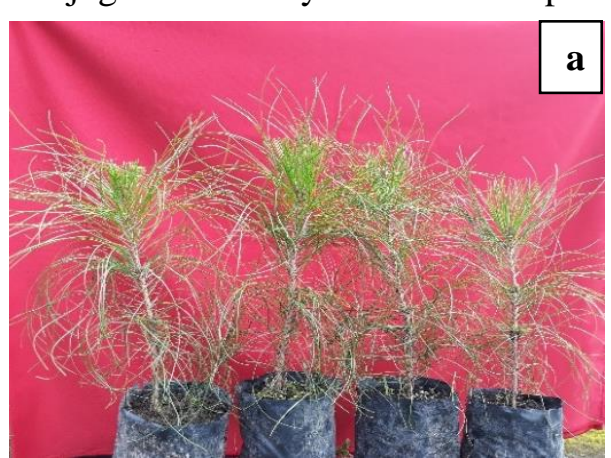

beberapa pangkal daun. Miselium yang berwarna putih itu lama-kelamaan akan berubah warna menjadi coklat kemudian mengering dan mati. Perkembangan pertumbuhan dan infeksi Pestalotia sp. terhadap semai pinus cukup cepat karena gejala diatas muncul sehari setelah inokulasi.

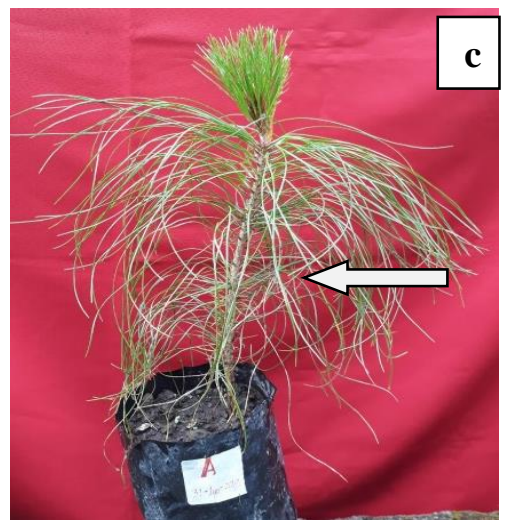

Gambar 4. (a) Semai pinus sebelum inokulasi, (b) Semai pinus setelah inokulasi (0 hari), (c) Semai pinus setelah inokulasi (13 hari)

Gejala tersebut menyebabkan kecoklatan tersebut meluas sampai batang perubahan warna daun yang diawali dari ujung, sehingga lambat laun semai pinus mengalami pangkal atau tengah daun dimana warna kematian.
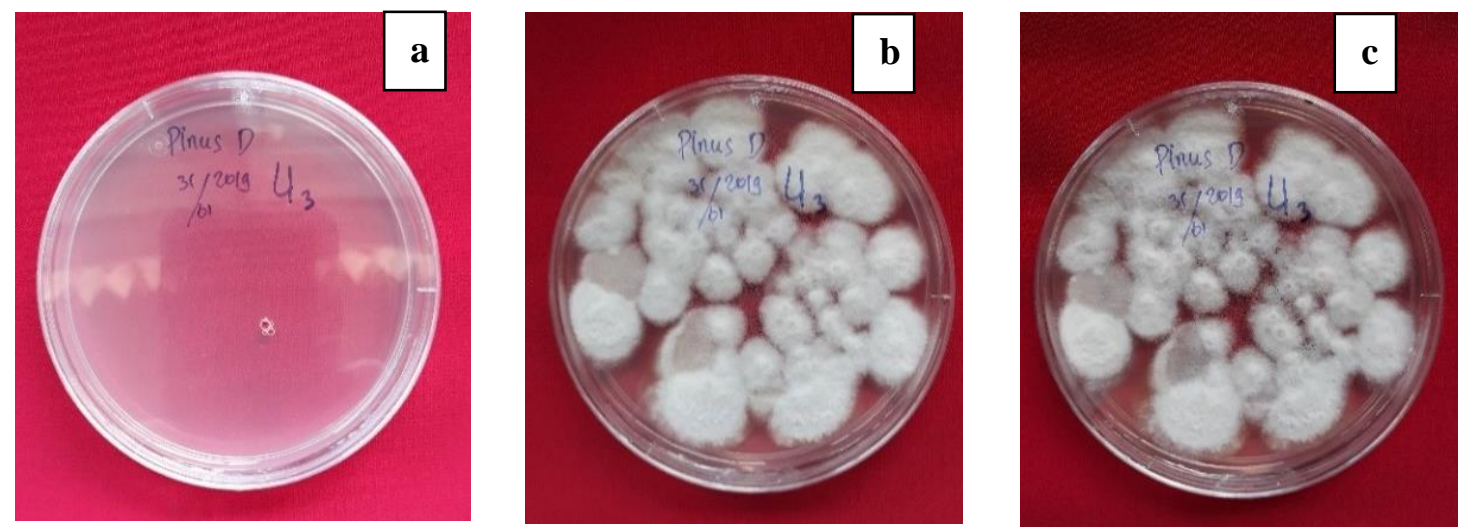

Gambar 5. (a) Plating Pestalotia sp. isolat D-U3 Hari ke-1, (b) Plating Pestalotia sp. isolat D-U3 Hari ke-8, (c) Plating Pestalotia sp. isolat D-U3 Hari ke-15

Uji patogenitas Pestalotia sp pada tanaman Chamaecyparis lawsoniana juga menunjukkan gejala yang serupa, gejala baru muncul 4 hari setelah inokulasi yaitu muncul 
bercak putih pada ujung permukaan atas daun, bercak berkembang ke arah petiola (hari ke-5), jumlah bercak meningkat (hari ke-6 dan 7), bercak berubah warna menjadi kuning kecoklatan dan terdapat aservuli berwarna hitam (hari ke-8), jumlah bercak berwarna gelap dan aservuli meningkat (hari ke-9) dan pada hari ke -10 terjadi nekrosis (Motlagh \& Rad, 2017).
Kegiatan plating dilakukan untuk memastikan bahwa isolat yang digunakan untuk inokulasi adalah benar jamur Pestalotia sp. yang menyebabkan penyakit bercak daun. Secara makroskopis (Gambar 5) dan mikroskopis hasil plating menunjukkan isolat yang sama dengan isolat jamur hasil isolasi (Gambar 6).

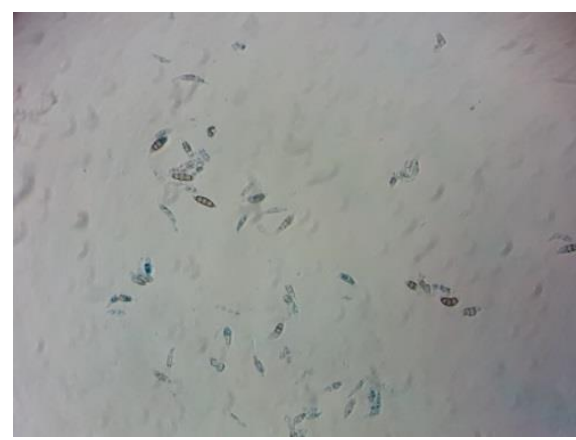

Gambar 6. Jamur Pestalotia sp. hasil plating yang dilihat di bawah mikroskop dengan perbesaran 20x

\section{KESIMPULAN}

Hasil identifikasi menunjukkan bahwa penyebab penyakit bercak daun pada semai Pinus adalah jamur Pestalotia sp. Karakter morfologi jamur patogen Pestalotia sp. yaitu memiliki miselium berwarna putih, tekstur seperti kapas, bentuk tidak teratur, memiliki hifa bersekat, bercabang dan berwarna gelap, serta terdapat konidia berbentuk lonjong agak meruncing pada kedua ujungnya yang salah satu ujungnya terdapat bulu cambuk yang berjumlah 3 atau 5.

\section{UCAPAN TERIMA KASIH}

Penelitian dilakukan dengan anggaran kerjasama Project ACIAR No. FST 2014/068 Balai Besar Penelitian dan Pengembangan Bioteknologi dan Pemuliaan Tanaman Hutan. Penulis menyampaikan ucapan terima kasih kepada Tim Project ACIAR No. FST 2014/068 di BBPPBPTH, dan juga kepada Dr. Rina Laksmi Hendrati, yang telah membimbing penulis dalam penulisan naskah serta semua pihak yang telah membantu dalam pelaksanaan penelitian dan penyediaan referensi dalam penulisan naskah.

\section{DAFTAR PUSTAKA}

Akrofi, A. Y., \& Amoah, F. M. (2009). Pestalotia spp. causes leaf spot of Vitellaria paradoxa in Ghana. African Journal of Agricultural Research, 4(4), 330-333.

Anggraeni, I. (2009). Colleotrichum sp Penyebab Penyakit Bercak Daun Pada Beberapa Bibit Tanaman Hutan di Persemaian. Mitra Hutan Tanaman, 4(2), 29-35.

Anggraeni, I., Intari, S. E., \& Darwiati, W. (2006). Hama dan Penyakit Hutan Tanaman. Bogor.

Anggraeni, I., \& Mindawati, N. (2011). Serangan Hama dan Penyakit pada Gmelina (Gmelina arborea Roxb.) di Hutan Rakyat. Tekno Hutan Tanaman, 2(2), 85-91.

Arsensi, I., Lahjie, A. M., Simarangkir, B. D. A. S., \& Mardji, D. (2016). Leaf Diseases On Eucalyptus pellita $\mathrm{F}$. Muell In Plantation Of Pt Surya Hutani Jaya At Sebulu , East Kalimantan. International Journal of Scientific \& Technology Research, 5(12), 10-15.

Bambang, Y., Diba, F., \& Anwari, S. (2019). Identifikasi serangga dan penyakit di areal persemaian PT. sari Bumi Kusuma di Kecamatan Bukit Raya Kabupaten Katingan, Kalimantan Tengah. Jurnal Hutan Lestari, 7(3), 1478-1485.

Barnett, H. L., \& Hunter, B. B. (1972). Illustrated Genera of Imperfect Fungi (4th Editio). Minneapolis: Burgess Publishing Co. 
Fatima, S., \& Khot, Y. C. (2017). Isolation of Post Harvest Fungi From Mango (Mangifera indica) fruits. International Journal of Multidiciplinary Research, III(V), 39-45.

Gao, F., Dai, C., \& Liu, X. (2010). Mechanisms of fungal endophytes in plant protection against pathogens. African Journal of Microbiology Research, 4(13), 1346-1351.

Garret, K., M, N., ED, W., PD, D. E., L, G.-M., \& AH, S. (2016). Chapter 21-Plant pathogens as indicators of climate change. In Climate change (second, pp. 325-338).

Hariyanto, T., Jumani, \& Heni, E. (2014). Identifikasi Hama dan Penyakit Shorea Leprosula Miq di Taman Nasional Kutai Resort Sangkima Kabupaten Kutai Timur Provinsi Kalimantan Timur. Agrifor, 9(2), 175-184.

Hidayah, H. N., \& Anggraeni, I. (2015). Identifikasi penyebab penyakit bercak merah pada bibit jabon merah (Anthocephalus macrophyllus (Roxb.) Havil) di persemaian permanen Kima Atas, Balai Penelitian Kehutanan Manado. Jurnal Wasian, 2(2), 73-78.

Irawan, A., Anggraeni, I., \& Christita, M. (2015). Identifikasi penyebab penyakit bercak daun pada bibit cempaka (Magnolia elegans (Blume.) H. Keng) dan teknik pengendaliannya. Jurnal Wasian, 2(2), 87-94.

Jarial, K., \& Jarial, R. (2016). Association of Pestalotia carissae with Carissa carandas: A new record from Himachal Pradesh. Indian Phytopath, 69(4s), 58-60.

Jarial, K., Jarial, R. S., Thakur, P. D., Banyal, S. K., \& Mandradia, R. K. (2017). Pestalotia versicolor a Predominant Pathogen Associated with Decline Disease of Mango in Sub-tropical Zone of Himachal Pradesh. International Journal of Bio-Resource and Stress Management, 8(1), 122-128.

Madhi, Q. H. (2016). Isolating and diagnose of the fungus Pestalotia spp that causes spotted leaves for four plants collected from some nurseries of the province of Maysan / Iraq Isolating and diagnose of the fungus Pestalotia spp that causes spotted leaves for four plants co. European Academic Research, IV(3), 2760-2772.

Manikandan, R., Ramya, V., Gokila, C., Rm, S., L, D. J., Harisanadevi, C., Parthasarathy, S. (2019). Survey report of major plant diseases in Chinnamanur block of Theni District, Tamil Nadu. The Pharma Innovation Journal, 8(5), 321-326.

Mehta, N., Jain, A., \& Rajkumar, M. (2020). Impact of pruning of Diospyros melanoxylon Roxb . (Tendu) bushes on yield and quality of leaves in Maharashtra. Journal of Pharmacognosy and Phytochemistry, 9(1), 1360-1365.

Moshayedi, M., Rahanandeh, H., \& Hamzeh, A. (2017). In vitro Evaluation of Some Fungicides and Tea Extract Against Pestalotia sp. and Colletotrichum sp., The Causal. Journal of Ornamental Plants, 7(1), 45-51.

Motlagh, M. R. S., \& Rad, F. R. (2017). Pathogenicity of Fungal Agents Related to the Diseases of Conifers of Cupressaceae in Greenhouse Conditions. Jurnal of Ornamental Plants, 7(3), 177-187.

Mouden, N., Benkirane, R., Touhami, A. O., \& Douira, A. (2014). Pathogenic capacity of Pestalotia longisetula Guba reported for the first time on strawberry (Fragaria ananassa Duch.) in Morocco. International Journal of Pure \& Aplied Bioscience, 2(4), 132-141.

Moustafa, M. S. H., Hala, A. M., El-Dakar, \& Alkolaly, A. M. (2015). Pestalotia leaf spot a New Disease affect Guava Trees in Egypt. International Journal of Scientific \& Engineering Research, 6(10), 1306-1312.

Olasupo, O. O., Adegeye, A. O., \& Olajuyigbe, S. O. (2020). Evaluation of micro-fungi associated with leaf spot of Allanblackia floribunda Oliv. in Southern Nigeria. African Journal of Microbiology Research, 14(8), 380-387. http://doi.org/10.5897/AJMR2020.9307

Patil, V. A., Mehta, B. P., Deshmukh, A. J., \& Bavalgave, V. G. (2019). Fungicides for the Management of Grey Leaf Blight (Pestalotia anacardii) of Mango. International Journal of Economic Plants, 6(2), 90-92.

Perhutani. (1999). Selayang pandang persemaian permanen Pongpoklandak KPH Cianjur. Cianjur.

Rabuansyah, B., Iskandar, \& Suryatini, R. (2014). Masa inkubasi penyakit karat daun dan tingkat kerusakan pada bibit perupuk (Lophopetalum multinervium) di persemaian PT. INHUTANI II Mandor. Jurnal Hutan Lestari, 2(3), 394400 .

Rahman, S., Adhikary, S. K., Sultana, S., \& Jahan, N. (2013). In vitro Evaluation of Some Selected Fungicides against Pestalotia palmarum (Cooke.) Causal Agent of Grey Leaf Spot of Coconut. Journal of Plant Pathology \& Microbiology, 4(9), 9-11. http://doi.org/10.4172/2157-7471.1000197

Raitelaitytė, K., Rutkauskas, A., \& Žukauskienè, J. (2016). The fungal pathogens causing diseases in pines. Biologija, 62(4), 276-283. 
Saragi, S. M., Firdara, E. K., \& Putir, P. E. (2019). Identifikasi, Frekwensi dan Intensitas Serangan Hama Penyakit pada Shorea balangeran (Korth.) Burck pada Persemaian BPDASHL Kahayan, Tumbang Nusa, Kalimantan Tengah. Jurnal Hutan Tropika, XIV(1), 51-59.

Semangun, H. (2000). Penyakit-penyakit tanaman perkebunan di Indonesia. Yogyakarta: Gadjah Mada University Press.

Semangun, H. (2006). Pengantar Ilmu Penyakit Tumbuhan. Yogyakarta: Gadjah Mada University Press.

Sharma, M., \& Kulshrestha, S. (2015). Colletotrichum gloeosporioides: An anthracnose causing pathogen of fruits and vegetables. Biosciences Biotechnology Research Asia, 12(2), 1233-1246. http://doi.org/https://doi.org/10.13005/bbra/177 6

Sinaga, M. S. (2000). Dasar-dasar ilmu penyakit tumbuhan. Bogor: IPB Press.

Streets, R. B. (1972). The Diagnosis of Plant Diseases: A Field and Laboratory Manual. Tucson, USA: University of Arizona Press.

Suharti, T., \& Kurniaty, R. (2013). Inventarisasi penyakit daun pada bibit di stasiun penelitian Nagrak. Jurnal Perbenihan Tanaman Hutan, 1(1), 51-59.

Supriyanto, \& Iskandar, T. (2018). Penilaian Kesehatan Kebun Benih Semai Pinus merkusii Dengan Metode FHM (Forest Health
Monitoring) di KPH Sumedang Health Assessment for Seedling Seed Orchard of Pinus merkusii Using FHM ( Forest Health Monitoring ) Method in KPH Sumedang. Jurnal Silvikultur Tropika, 9(2), 99-108.

Sutarman. (2018). Status dan mitigasi dini serangan pinus di Jawa Timur. (S. C. S. Rasminah \& D. Satiti, Eds.). Sidoarjo: UMSIDA PRESS, P3I Universitas Muhammadiyah Sidoarjo.

Sutarman, \& Prihatiningrum, A. E. (2015). Penyakit hawar daun Pinus merkusii di berbagai persemaian kawasan utama hutan pinus Jawa Timur. J. HPT Tropika, 15(1), 44-52.

Wadud, M., Fahim, A. H. F., Sarker, M. B., \& Uddin, M. J. (2017). Management of grey leaf spot/blight disease of bay leaf (Cinnamomum tamala). Eco-Friendly Agril.J, 10(7), 90-95.

Wonni, I., Sereme, D., Quedraogo, I., Kassankagno, A. I., Dao, I., Quedraogo, L., \& Nacro, S. (2017). Diseases of Cashew Nut Plants (Anacardium Occidentale L.) in Burkina Faso. Adv Plants Agric Res, 6(3). http://doi.org/10.15406/apar.2017.06.00216

Yimcharoen, C., Tongon, R., Song, J., \& Soytong, K. (2019). Bioactivity test of Chaetomium isolate CNC1 to control Pestalotia spp causing leaf spot of Orchird. In Proceeding of The 8th International Conference on Integration of Science and Technology for Sustainable Development (8th ICIST) in November 19-22, 2019 at Huiyuan International Hotel, Jingde, Anhui Province, P.R. China. (pp. 165-169). 